\title{
Renal involvement in epidermolysis bullosa patients: a case series study
}

\section{Case series}

Epidermolysis_bullosa (EB) is a group of heritable diseases characterized by trauma-induced excessive skin and mucosal fragility. ${ }^{1}$ Besides the skin manifestations, different EB types have a different risk to develop extracutaneous complications. ${ }^{2}$ It has been described that a small but clinically significant portion of EB patients develops major nephro-urological complications, affecting mainly Junctional EB (JEB) and Recessive Dystrophic EB (RDEB) patients. ${ }^{3,4}$ These complications have a strong influence on patient's quality of life and in the most severe cases, are their principal cause of death. ${ }^{3}$ DEBRA Chile is the only referral unit for EB patients in Chile, and currently their registry contains 225 patients from all EB types. From these 225 patients, eight are JEB and 64 are RDEB, with age range from 3 to 22 years old for JEB and from 0 to 76 years old for RDEB. Patients are periodically evaluated for cutaneous and extracutaneous manifestations, including renal function. ${ }^{5}$ Laboratory tests (blood and urine) are performed in patients with suspicion of renal involvement, specifically looking at renal dysfunction (urinary nitrogen/plasmatic creatinine, serum amyloid A and electrolytes in plasma), hematuria (urinalysis) and proteinuria (micro albuminuria). When a urological cause is discarded, a renal biopsy is highly advice to obtain a specific diagnosis, and eventually its, treatment and prognosis. The biopsy is afterwards sent for histopathology analysis, which includes light microscopy, immune fluorescence and electron microscopy.

In the last 6 years, eight patients have been diagnosed with renal disease; all classified as RDEB patients by skin biopsy (Table 1). From these 8 cases, 6 underwent a renal biopsy, and the procedure was performed without complications. In the other 2 cases, families declined a renal biopsy because of the invasiveness of the procedure; however, in both cases, the clinical characteristics suggest an IgA nephropathy. The mean age for patients with suspicion of renal involvement was 16 years old (ranging from 13 to 28 years old), with a slight overrepresentation of male over female patients $(5 / 8)$. Diagnoses were highly variable, 5 different diagnoses were found in 8 different patients, being the IgA nephropathy the most common diagnosis observed (2/8 confirmed and 2/8 highly suspected). Interestingly, patients from our case series were mainly carrying mutations predicting to cause absent type VII collagen protein $(6 / 8)$. This observation could be interpreted, as the absence of this protein in the kidney might contribute to a higher risk of renal damage, as it happens with blister induction on the skin. However, it is important to note that most RDEB patients are often infected with multidrugresistant bacteria and on a constant chronic inflammatory state, which are proven to be major players for most of the extra cutaneous complications in EB, including renal disease. ${ }^{6}$

No JEB patients were diagnosed with renal involvement, although 16 patients were alive at some point of this period. A possible explanation is a lower life expectancy when compared with other populations. ${ }^{7}$ It has been observed that more than $70 \%$ of our JEB patients die before the age of 10, and mainly due to sepsis and respiratory failure. ${ }^{8}$ Patients with a biopsy-confirmed IgA nephropathy were treated with oral corticosteroids for 12 weeks, one of them showed a good clinical response. Two patients develop renal terminal
Volume 8 Issue 4 - 2018

\author{
F Cavagnaro,' MJ Yubero, ${ }^{1,2}$ I Fuentes, ${ }^{2,3} \mathrm{~F}$ \\ Palisson ${ }^{1,2}$ \\ 'Clínica Alemana de Santiago, Facultad de Medicina Clínica \\ Alemana-Universidad del Desarrollo, Santiago, Chile \\ ${ }^{2}$ Fundación DEBRA, Chile \\ ${ }^{3}$ Center of Genetics and Genomics, Facultad de Medicina \\ Clínica Alemana-Universidad del Desarrollo, Santiago, Chile
}

Correspondence: Felipe Cavagnaro, MD, Facultad de Medicina Clínica Alemana-Universidad del Desarrollo, Santiago, Chile, Email fcavagnaro@alemana.cl

Received: January 28, 2018 | Published: July 25, 2018

failure managed initially with peritoneal dialysis and are currently on hemodialysis. The patient with renal amyloidosis was treated with colchicine for 3 months, but died of sepsis with multiple organ failure, at the age of 22 years. The patient with mesangiocapillary glomerulonephritis type $1 \mathrm{did}$ not require treatment.

The pathogenesis of renal damage is complex and several factors are involved:

A. Frequent antibiotic therapies based on aminoglycosides, notoriously nephrotoxic, used to treat renal and skin infections.

B. Cytokine release, particular amyloid A protein, which, in EB patients, may lead to renal failure.

C. Immuno complexes, deposited in glomerular capillary basement membranes, or in the mesangium, resulting in post-infectious glomerulonephritis, IgA glomerulonephritis, or mesangio proliferative glomerulonephritis, ${ }^{9}$ besides the renal damage secondary to urinary tract stenosis/obstruction and associated infections. ${ }^{4,7}$

All these conditions can lead to chronic renal failure, although it is a rare cause of death in pediatric population. ${ }^{10}$ For EB patients, some of the long-term renal consequences can be avoided by a routine symptom/signs screening followed by a diagnosed-specific clinical management. ${ }^{11,12}$ As our results showed, hematuria was the most common renal phenotype observed on EB patients (6/8). This phenotype can be caused by glomerular or extra glomerular damage, the latter being easily discarded by performing urine tests and a renal/ bladder ultrasound. However, if a kidney insult cannot be excluded by laboratory and image tests, a renal biopsy should be advice for obtaining a specific diagnosis. Renal involvement monitoring should be included in the standard of care, starting as early as an diagnosis EB is made. In this sense, there are currently no published guidelines on how to monitor these patients. Almaani and Mellerio recommend that a 6-monthly serum urea and electrolytes, blood pressure, and urinalysis be performed in all patients belonging to the most severe EB types; RDEB gen sev and JEB gen sev. ${ }^{3}$ We also proposed a kidney and bladder ultra sound annually, even without signs of abnormalities 
in the urine exam. If available, urine tests should be taken when a sphincter control is obtained since the use of probes or collectors (by adhesives) in patients with EB are not recommended. In the case of

Table I Overview of patients with nephro-urological complications

\begin{tabular}{|c|c|c|c|c|c|c|c|c|}
\hline Patient $n^{\circ}$ & $\mathbf{I}$ & 2 & 3 & 4 & 5 & 6 & 7 & 8 \\
\hline Gender & $\mathrm{F}$ & $M$ & $M$ & M & $\mathrm{F}$ & M & $\mathrm{F}$ & $M$ \\
\hline Type of EB & RDEB gen sev & $\begin{array}{l}\text { RDEB gen } \\
\text { sev }\end{array}$ & $\begin{array}{l}\text { RDEB gen } \\
\text { sev }\end{array}$ & RDEB gen intermed & $\begin{array}{l}\text { RDEB gen } \\
\text { sev }\end{array}$ & $\begin{array}{l}\text { RDEB gen } \\
\text { sev }\end{array}$ & $\begin{array}{l}\text { RDEB gen } \\
\text { sev }\end{array}$ & $\begin{array}{l}\text { RDEB gen } \\
\text { sev }\end{array}$ \\
\hline Mutations & $\begin{array}{l}\text { c. [7708delG] } \\
+[7708 \mathrm{del} G]\end{array}$ & $\begin{array}{l}\text { c. [7708delG] } \\
+[7708 \mathrm{del}]\end{array}$ & $\begin{array}{l}\text { c. }[5932 \mathrm{C}>\mathrm{T}] \\
+[5932 \mathrm{C}>\mathrm{T}]\end{array}$ & $\begin{array}{l}\text { c. }[5532+\mid \mathrm{G}>\mathrm{T}]+ \\
{[8245 \mathrm{G}>\mathrm{A}]}\end{array}$ & ND & $\begin{array}{l}\text { c. [6527insC] } \\
+[7708 \mathrm{delG}]\end{array}$ & $\begin{array}{l}\text { c.[7708delG] } \\
+[7708 \mathrm{delG}]\end{array}$ & $\begin{array}{l}\text { c. }[6527 \text { ins C }] \\
+[6527 \text { ins } C]\end{array}$ \\
\hline $\begin{array}{l}\text { Protein } \\
\text { consequence }\end{array}$ & $\begin{array}{l}\text { Absent } \\
\text { protein }\end{array}$ & $\begin{array}{l}\text { Absent } \\
\text { protein }\end{array}$ & $\begin{array}{l}\text { Absent } \\
\text { protein }\end{array}$ & $\begin{array}{l}\text { Slighlty different } \\
\text { protein }\end{array}$ & ND & $\begin{array}{l}\text { Absent } \\
\text { protein }\end{array}$ & $\begin{array}{l}\text { Absent } \\
\text { protein }\end{array}$ & $\begin{array}{l}\text { Absent } \\
\text { protein }\end{array}$ \\
\hline $\begin{array}{l}\text { Age at clinical } \\
\text { diagnosis } \\
\text { (years) }\end{array}$ & 13 & 13 & 19 & 28 & 16 & 21 & 17 & 16 \\
\hline $\begin{array}{l}\text { Clinical signs } \\
\text { for renal } \\
\text { failure }\end{array}$ & $\begin{array}{l}\text { Persistent } \\
\text { macroscopic } \\
\text { hematuria }\end{array}$ & $\begin{array}{l}\text { Renal } \\
\text { Insufficiency } \\
\text { Stage } 3\end{array}$ & $\begin{array}{l}\text { Nephritic } \\
\text { syndrome + } \\
\text { Azotemia }\end{array}$ & $\begin{array}{l}\text { Macroscopic } \\
\text { hematuria in } \\
\text { the context of } \\
\text { hospitalization for } \\
\text { convulsive syndrome }\end{array}$ & $\begin{array}{l}\text { Macroscopic } \\
\text { hematuria + } \\
\text { Proteinuria }\end{array}$ & $\begin{array}{l}\text { Hematuria } \\
+ \text { Nefrotic } \\
\text { proteinuria } \\
+ \text { RF }\end{array}$ & $\begin{array}{l}\text { Persistent } \\
\text { macroscopic } \\
\text { hematuria }\end{array}$ & $\begin{array}{l}\text { Macroscopic } \\
\text { hematuria + } \\
\text { Proteinuria }\end{array}$ \\
\hline Biopsy result & $\begin{array}{l}\text { IgA } \\
\text { nephropathy }\end{array}$ & $\begin{array}{l}\text { Chronic } \\
\text { interstitial } \\
\text { nephritis }\end{array}$ & $\begin{array}{l}\text { PIGN with } \\
\text { crecentics }\end{array}$ & MCG type I & $\begin{array}{l}\text { IgA } \\
\text { nephropathy }\end{array}$ & $\begin{array}{l}\text { Renal } \\
\text { amyloidosis }\end{array}$ & ND & ND \\
\hline Treatment & Steroids $\$$ & Dialysis & Dialysis & NT & Steroids $\$$ & Colchicine & NT & NT \\
\hline $\begin{array}{l}\text { Clinical } \\
\text { Otcome }\end{array}$ & $\begin{array}{l}\text { Regression of } \\
\text { Hematuria }\end{array}$ & $\begin{array}{l}\text { ESRD in } \\
\text { dialysis\# }\end{array}$ & $\begin{array}{l}\text { ESRD in } \\
\text { dialysis\# }\end{array}$ & $\begin{array}{l}\text { Regression of } \\
\text { Hematuria }\end{array}$ & Unknown* & $\begin{array}{l}\text { Dies from } \\
\text { Amyloidosis } \\
\text { and Sepsis }\end{array}$ & $\begin{array}{l}\text { Stable } / \\
\text { untreated } \\
\text { hematuria }\end{array}$ & $\begin{array}{l}\text { Stable / } \\
\text { untreated } \\
\text { hematuria }\end{array}$ \\
\hline
\end{tabular}

F, Female; M, male; gen sev, generalized severe; gen in termed, generalized intermediate; ND, not done; NT, not treated; RF, Renal Failure; PIGN, Post infectious Glomerulonephritis; MCG, mesangio capillary glomerulonephritis; ESRD, End Stage Renal Disease; \$ Steriod treatment consisted of oral prednisone at a dose of $2 \mathrm{mg} / \mathrm{kg}$ for 12 weeks. Patients present no adverse effects (only Cushing's syndrome) and we observed an improvement on skin lesions during the treatment; *Patient return to Perú after the treatment. We presume a positive clinical response because she has not return for follow ups since then, May 20II; \#These 2 patients have been over a year in dialysis and are currently stable. However, one of them developed congestive heart failure due to hypertensive cardiomyopathy. Mutations numbering are on the COL7AI cDNA reference model, NM 000094.3. Protein consequences were calculated theoretically taking into account the position of the mutation in the CDNA, the protein change and nonsense mediated decay.

\section{Acknowledgements}

We thank the doctors A Ayala and M Schultz for their collaboration with these patients.

\section{Funding sources}

This work was supported by FONDECYT (grant number 11140440).

\section{Conflicts of interest}

None declared.

\section{References}

1. Fine JD, Bruckner-Tuderman L, Eady RA, et al. Inherited epidermolysis bullosa: updated recommendations on diagnosis and classification. $\mathrm{J} \mathrm{Am}$ Acad Dermatol. 2014;70(6):1103-1126.

2. Murat-Susic S, Husar K, Skerlev M et al. Inherited Epidermolysis Bullosa-the Spectrum of Complications. Acta Dermatovenerol Croat. 2011;19:255-263. any abnormalities are detected, appropriate imaging or functional tests should be performed and specialist urological or renal opinions sought. 
10. Fine JD, Johnson LB, Weiner M, et al. Cause-specific risks of childhood death in inherited epidermolysis bullosa. J Pediatr. 2008;152(2):276280 .

11. Kaneko K, Someya T, Ohtaki R et al. Colchicine therapy in amyloid nephropathy due to recessive dystrophic epidermolysis bullosa. Pediatr Nephrol. 2003;18(12):1311-1312.
12. Ungurenau S, Adni T, Brown T et al. Successful renal transplant in a patient with non-Herlitzjunctionalepidermolysis bullosa. Clin Exp Dermatol. 2014;39(3):330-332. 